\title{
Aplikasi Screen Lock pada Smartphone Menggunakan Identifikasi Wajah dengan Menerapkan Pointwise
}

\author{
Andi Widiyanto*1, Bintang Dian Mahardika ${ }^{2}$ \\ ${ }^{1,2}$ Teknik Informatika Universitas Muhammadiyah Magelang \\ E-mail: ${ }^{* 1}$ andi.widiyanto@ummgl.ac.id, ${ }^{2}$ dekha_clickers@gmail.com
}

\begin{abstract}
Abstrak
Penerapan identifikasi wajah (face recognition) telah diterapkan pada komputer, laptop atau alat-alat lain yang memang dikhususkan untuk identifikasi wajah. Perkembangan smartphone khususnya android berkembang dengan cepat. Untuk menjaga keamanan supaya hanya dapat digunakan oleh pemilik telah disediakan dengan PIN, phone code, pola geser titik sentuh layar. Aplikasi identifikasi wajah digunakan sebagai pengganti PIN atau code phone pada smartphone android dibutuhkan sebagai proteksi supaya hanya pemiliknya saja yang dapat menggunakannya. Supaya proses identifikasi wajah pemilik lebih mudah perlu dilakukan konversi dari gambar true color ke grayscale proses yang digunakan adalah pointwise. Aplikasi face recognition yang dibangun membutuhkan training wajah pemilik dengan 6 pose wajah yang disimpan, kemudian akan dibandingkan dengan identifikasi wajah saat aplikasi digunakan. Hasil pengujian menunjukkan bahwa tingkat keberhasilan antara 70\% - 90\%. Jarak antara wajah dan kamera serta tingkat kecerahan cahaya mempengaruhi hasil dari identifikasi wajah. Tingkat keberhasilan identifikasi wajah ditentukan oleh pengambilan image, pemrosesan image, dan perhitungan dengan PCA (eigenface).
\end{abstract}

Kata Kunci-Face recognition, smartphone, android, pointwise, eigenface

\begin{abstract}
Face recognition has been implemented on a computer, laptop or other device tool which is dedicated for face identification. Developments in particular android smartphones growing rapidly. To maintain the security that can only be used by owners have been provided with a PIN, phone code, pattern shear point touch screen. Face recognition application used as a substitute for or a PIN code on the phone android smartphone needed as protection so only the owner who can use it. So that the process of identification of the owner's face needs to be done easier conversion of true color images into grayscale process used is pointwise. Face recognition application that is built requires owners face training with 6 face pose saved, then will be compared with the face identification when the application is used. The test results showed that the success rate of between $70 \%-90 \%$. The distance between the face and the camera and the brightness of light affect the results of face identification. The success rate is determined by identifying the face image capture, image processing, and computation with PCA eigenface.
\end{abstract}

Keywords-Face recognition, smartphone, android, pointwise, eigenface 


\section{PENDAHULUAN}

Sistem operasi smartphone yang paling banyak digunakan adalah android. Android adalah sebuah sistem open source yang berkembang dengan pesat begitu pula dengan program aplikasi. Untuk menjaga keamanan supaya hanya dapat digunakan oleh pemilik telah disediakan dengan PIN, phonecode, pola geser titik sentuh layar.

Penerapan identifikasi wajah telah diterapkan pada komputer, laptop atau alat-alat lain yang memang dikhususkan untuk identifikasi wajah. Namun saat ini pengguna lebih cenderung menggunakan handphone atau smartphone daripada menggunakan laptop ataupun komputer dengan berbagai alasan misalnya kepraktisannya.

Pada penelitian ini rumusan masalah yang diangkat adalah bagaimana membangun aplikasi identifikasi wajah dengan pada smartphone android sebagai proteksi supaya hanya pemiliknya saja yang dapat menggunakannya.

Aplikasi identifikasi wajah (face recognition) digunakan sebagai pengganti PIN atau code phone pada smartphone android supaya hanya wajah pemilik saja yang dapat digunakan untuk membuka kunci (lock) smartphone yang terkunci oleh pemiliknya.

Image processing atau pengolahan gambar adalah bidang sendiri yang sudah cukup berkembang sejak orang mengerti bahwa komputer tidak hanya dapat menangani data teks, tetapi juga data gambar. Bidang - bidang yang termasuk dalam image processing meliputi penajaman gambar, penonjolan fitur tertentu dari suatu gambar, komponen gambar dan koneksi gambar yang tidak fokus atau kabur, pewarnaan pada gambar gray scale dan sebagainya [1].

Menurut Ridwan (2007)Point process atau pointwise merupakan salah satu teknik untuk melakukan pengolahan citra digital dengan cara mengubah nilai pixel yang asli berdasarkan nilai pixel tersebut. Pointwise juga dapat diterapkan dalam pengolahan citra truecolor menjadi gray scale[2].

Gray scale adalah konversi citra true color menjadi citra keabuan. Suatu istilah untuk menyebutkan satu citra yang memiliki warna abu-abu, hitam dan putih. Gray scale menunjukkan jumlah warna (dari abu-abu, hingga hitam - putih) yang ada dalam satu citra. Operasi konversi citra true color ke gray scale dapat Untuk mengubah citra berwarna yang memiliki nilai matrik masing-masing $R, G$, dan $B$ menjadi citra gray scale dengan membagi jumlah ketiga layer, dengan persamaan 1 .

$$
f_{0}(x, y)=\frac{f_{i}^{R}(x, y)+f_{i}^{G}(x, y)+f_{i}^{B}(x, y)}{3}
$$

Gambar diinput kemudian melalui perulangan untuk x (lebar) dan y (tinggi). $\mathrm{x}$ dan $\mathrm{y}$ adalah koordinat dari pixel. Kemudian dilanjutkan dengan mencari nilai dari red, green, blue dalam setiap pixel dan dioperasikan dalam penjumlahan kemudian dibagi oleh tiga. Hasilnya akan didapat nilai dari gray scale seperti pada gambar 1.

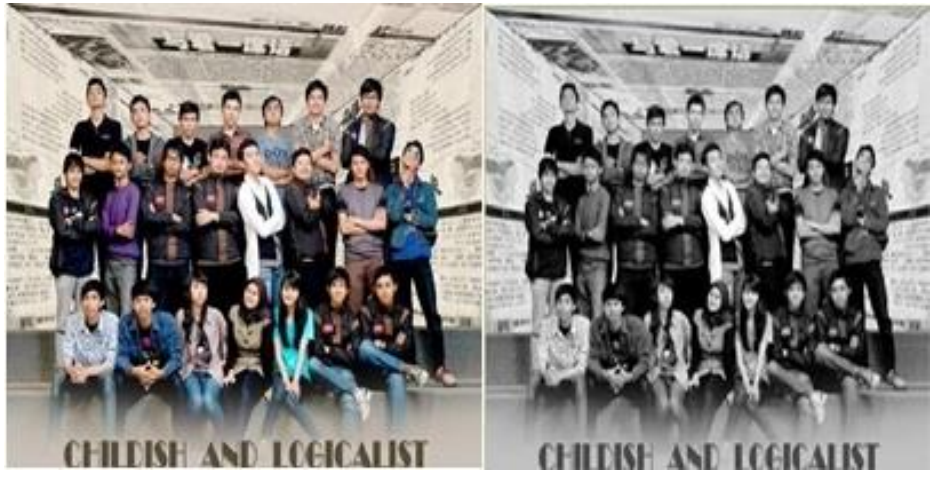

Gambar 1. Perubahan Citra True Color (kiri) menjadi citragray scale (kanan) 
Secara umum sistem pengenalan wajah dibagi menjadi 2 jenis, yaitu sistem feature base dan sistem image-based. Pada sistem pertama fitur lokal didapat dari proses ekstraksi komponen citra wajah seperti mulut, hidung, mata, pipi dan lain-lain yang kemudian di modelkan secara geometris hubungan antar fitur-fitur tersebut, sedangkan untuk sistem yang kedua menggunakan informasi mentah dari pixel citra yang kemudian direpresentasikan dalam metode tertentu, misalnya Principal Component Analysis (PCA), transformasi Wavelet, dan sebagainya, yang kemudian digunakan untuk pelatihan dan klasifikasi identitas citra [3].

Eigenface adalah salah satu algoritma pengenalan wajah yang didasarkan pada Participal Component Analysis (PCA) yang dikembangkan Mattew Turk dan Alex Pentland dari VisionandModeling Grup, The Media Laboratory, MIT (Massachusetts Institute of Tecnology) pada tahun 1987. Algoritma eigenface secara keseluruhan cukup sederhana. Training image direpresentasikan ke dalam sebuah vectorflat (gabungan vektor) dan digabung secara bersamasama menjadi sebuah matriks tunggal. Eigen Vectorkemudian diekstraksi dan disimpan dalam file temporary atau database. Training image kemudian diproyeksikan dalam feature space, dinamai face spaceyang ditentukan oleh eigen vector [3].

Android adalah sebuah sistem operasi untuk perangkat lunak mobile berbasis Linux yang mencakup sistem operasi, middleware dan aplikasi. Android SDK adalah tools API(Application Programming Interface)yangdiperlukan untuk mulai mengembangkan aplikasipadaplatformandroidmenggunakanbahasapemrogramanJava.Androidmerupakan

subsetperangkat lunakuntuk ponsel yang meliputi sistem operasi, middleware dan aplikasi kunci yang direlease oleh Google [4].

JavaCV merupakan wrapper untuk pustaka-pustaka yang umum digunakan untuk fungsi real time computer vision yang terdapat pada aplikasi OpenCV, FFmpeg, OpenKinect, dan ARToolKitPlus.Dengan menggunakan JavaCV maka pengembangan aplikasi yang menggunakan pustaka yang disebutkan diatas (umumnya $\mathrm{C}$ based) dapat dilakukan di environment Java [5].

\section{METODE PENELITIAN}

Penelitian ini metodologi penelitian menggunakan Model Sekuensial Linier menurut Roger S. Pressman. Model ini mengembangkan perangkat lunak dengan pendekatan yang sistematik dan sekuensial yang dimulai pada tingkat dan kemajuan sistem pada seluruh analisis, desain, kode, pengujian, dan pemeliharaan bagannya seperti pada gambar 2 .

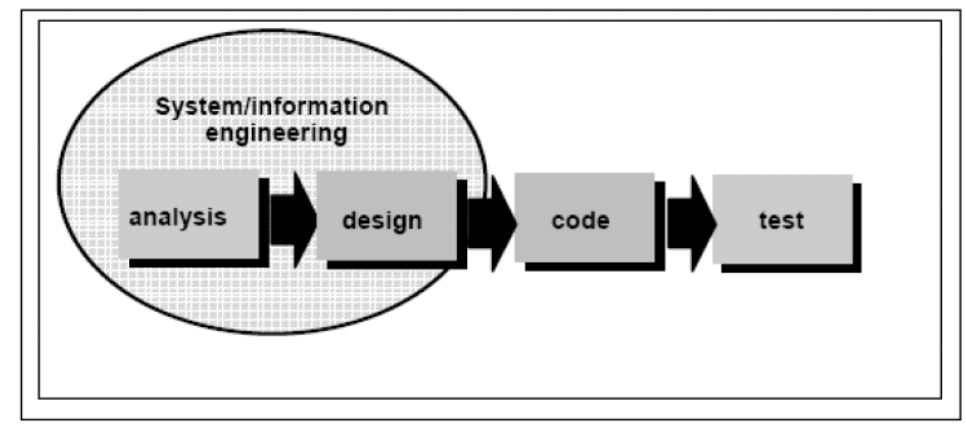

Gambar 2. Model Sekuensial Linier

Aplikasi identifikasi wajah (face recognition) yang digunakan sebagai pengganti PIN atau code phone pada smartphone android yang akan dibangun dengan menerapkan pointwise untuk pengolahan citra adalah pengubah citra RGB menjadi gray scale.

Sebuah gambar (true color) terdiri dari tiga layer yaitu, R-layer, G-layer, dan B-layer diubah menjadi satu layergray scale. Untuk mengubah citra berwarna yang memiliki nilai matriks masing-masing R, G, dan B menjadi citra gray scale dengan membagi jumlah ketiga layer seperti pada persamaan 1 . 
Proses konversi RBG ke gray scale melalui perhitungan manual, Misalkan sebuah gambar memiliki citra berukuran $3 \times 4$ pixel dengan nilai - nilai RBG-nya terlihat pada tabel 1 .

Tabel 1. RGB dengan pixel $3 \times 4$

\begin{tabular}{|c|c|c|c|c|}
\hline $\begin{array}{c}(\mathrm{x}, \\
\mathrm{y})\end{array}$ & 1 & 2 & 3 & 4 \\
\hline & 60 & 70 & 85 & 90 \\
1 & 63 & 66 & 55 & 86 \\
& 30 & 20 & 88 & 73 \\
\hline & 70 & 86 & 76 & 74 \\
2 & 40 & 75 & 55 & 84 \\
& 46 & 61 & 49 & 55 \\
\hline & 50 & 96 & 55 & 115 \\
3 & 100 & 54 & 100 & 117 \\
& 60 & 57 & 61 & 128 \\
\hline
\end{tabular}

Berikut ini adalah contoh pengolahan RGB ke gray scale pada kordinat fo $(1,1)$ dan fo $(3,4)$

$$
\begin{gathered}
f_{0}(1,1)=\frac{60+63+30}{3}=51 \\
f_{0}(3,4)=\frac{115+117+128}{3}=120
\end{gathered}
$$

Perhitungan tersebut dilakukan untuk setiap koordinat, sehingga matriks citra hasil konversi seperti pada tabel 2.

Tabel 2. Gray scale dengan pixel $3 \times 4$

\begin{tabular}{|c|c|c|c|c|}
\hline$(\mathrm{x}, \mathrm{y})$ & 1 & 2 & 3 & 4 \\
\hline 1 & 51 & 52 & 76 & 83 \\
\hline 2 & 52 & 74 & 60 & 71 \\
\hline 3 & 70 & 69 & 72 & 120 \\
\hline
\end{tabular}

Hasilnya akan didapatkan nilai dari gray scale. Untuk lebih jelasnya digambarkan dengan flowchart gambar 3. 
Citec Journal, Vol. 1, No. 1, November 2013 - Januari 2014

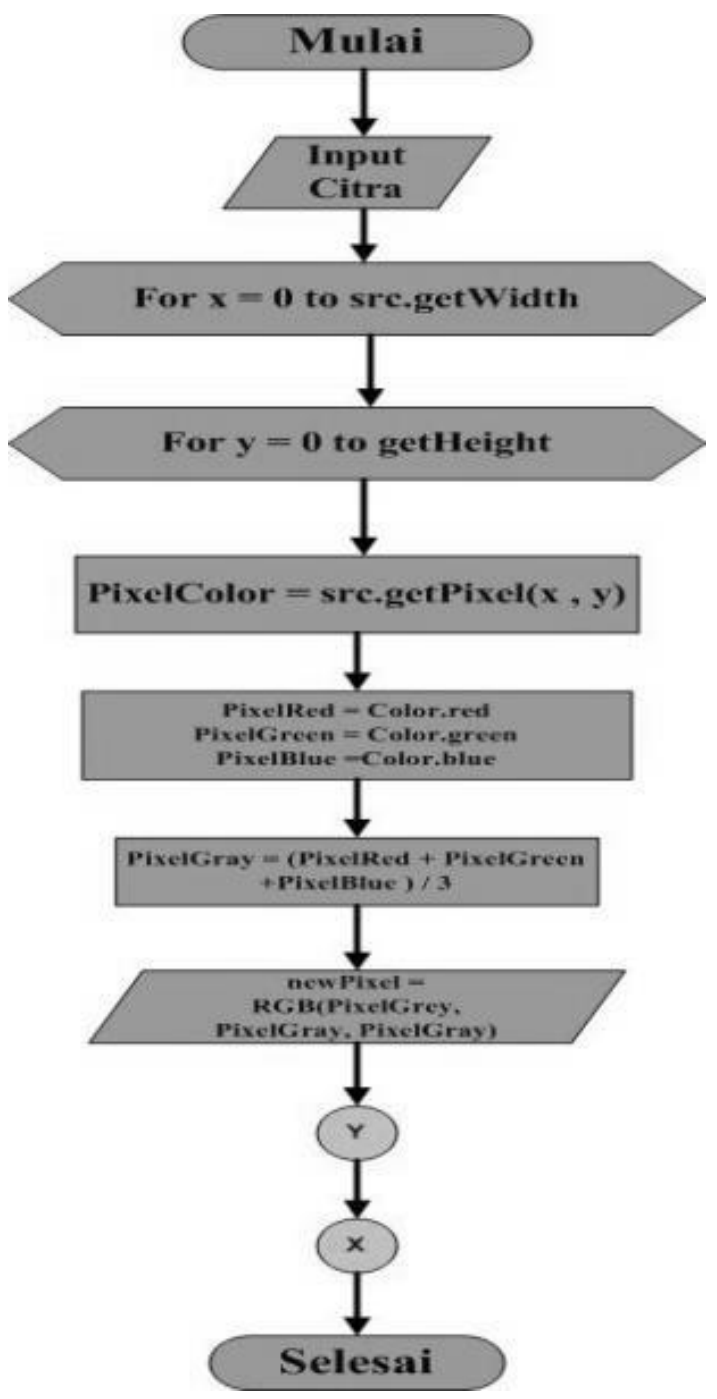

Gambar 3. Flowchart konversi ke gray scale

Proses selanjutnya adalah training dan identifikasi wajah untuk memproses menggunakan Algoritma eigenface.Image training wajah dari hasil capture yang telah diolah berupa gambar gray scale. Image diproyeksikan ke facespace dengan mengalikan di basis eigenface proyeksi vector wajah akan dibandingkan dengan vector yang sesuai. Ekstrak PCA image tes, Cari distance minimum dari image tes dan image training. Penjumlahan dengan hasil terkecil dengan nilai yang tidak bernilai negatif adalah wajah yang cocok dengan wajah tes digambarkan dalam bentuk flowchart yang dapat dilihat pada gambar 4 . 


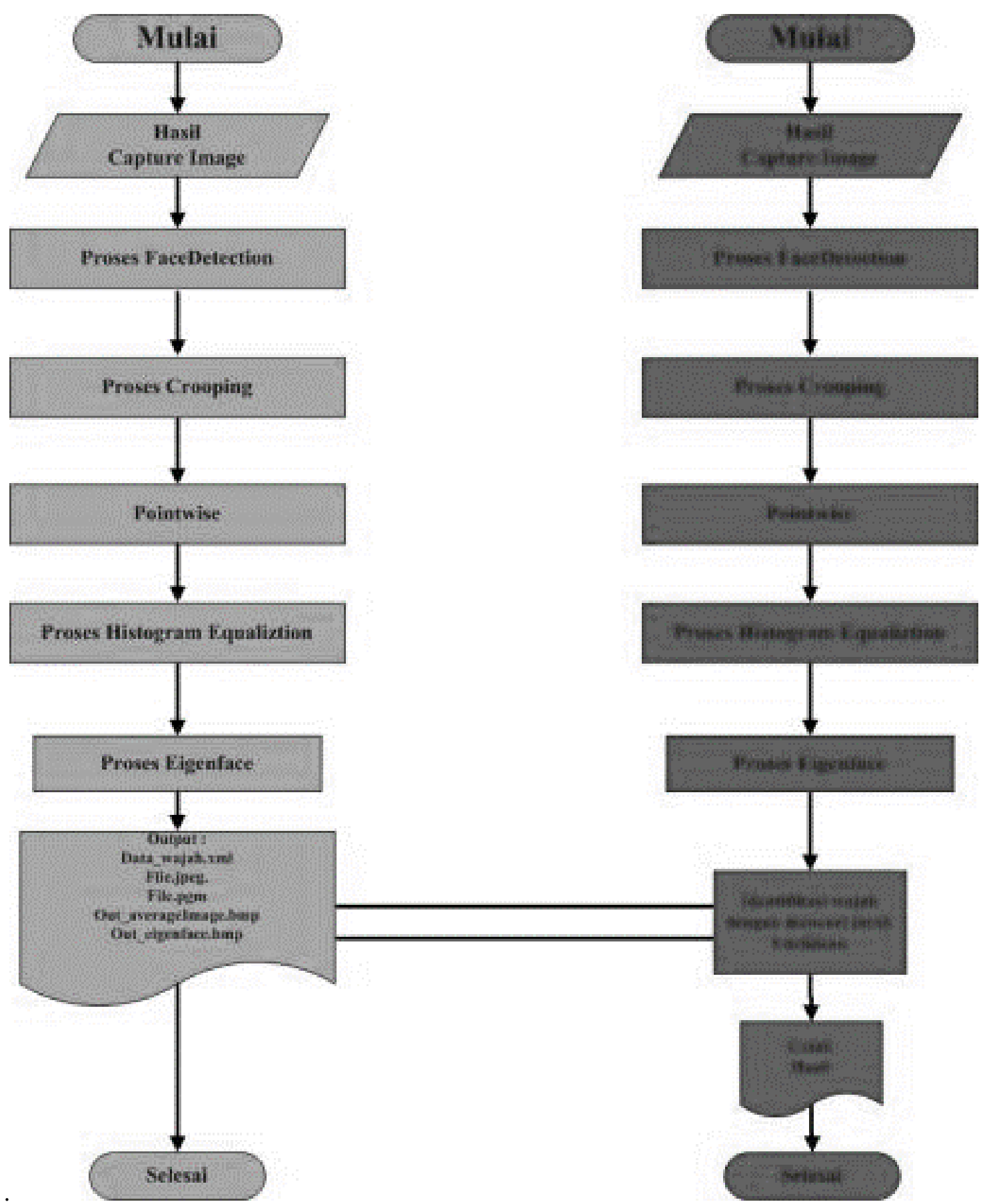

Gambar 4. Model Algoritma training wajah (kiri) dan identifikasi wajah (kanan)

Perancangan sistem yang digunakan untuk membangun aplikasi adalah dengan UML (Unified Modelling Language). UML adalah bahasa standar yang digunakan untuk menjelaskan dan memvisualisasikan artifak dari proses analisis dan desain berorientasi obyek. Pemodelan aplikasi digambarkan dengan diagram use case. Pengembangan aplikasi identifikasi wajah menggunakan metode eigenfae hanya terdapat satu actor seperti pada gambar 5. 
Citec Journal, Vol. 1, No. 1, November 2013 - Januari 2014

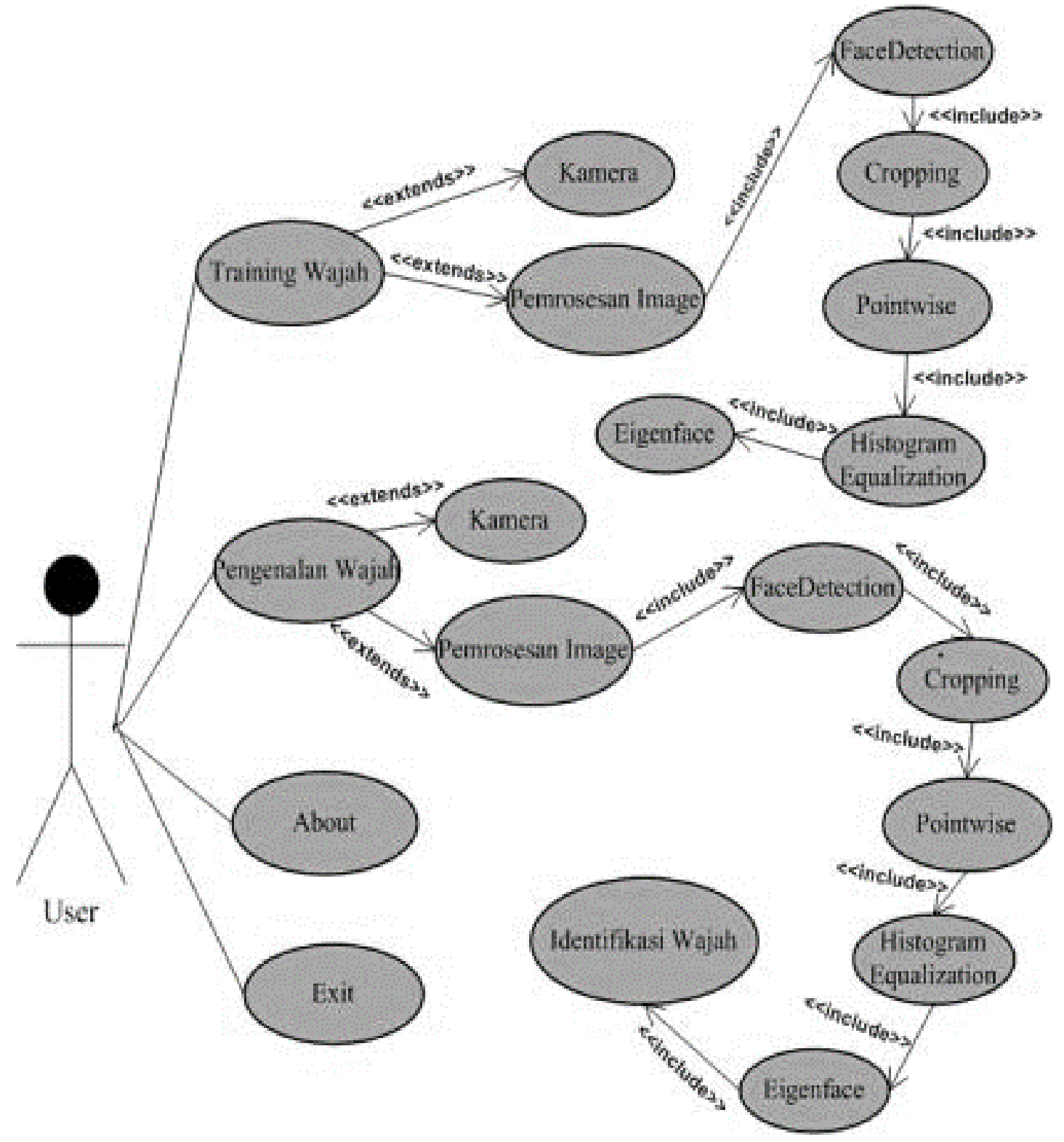

Gambar. 5 Use case Diagram aplikasi identifikasi wajah

Class diagram digunakan untuk menunjukkan hubungan antara class dalam aplikasi yang sedang dibangun dan bagaimana setiap class saling berkolaborasi untuk mencapai suatu tujuan seperti pada gambar 6 . 


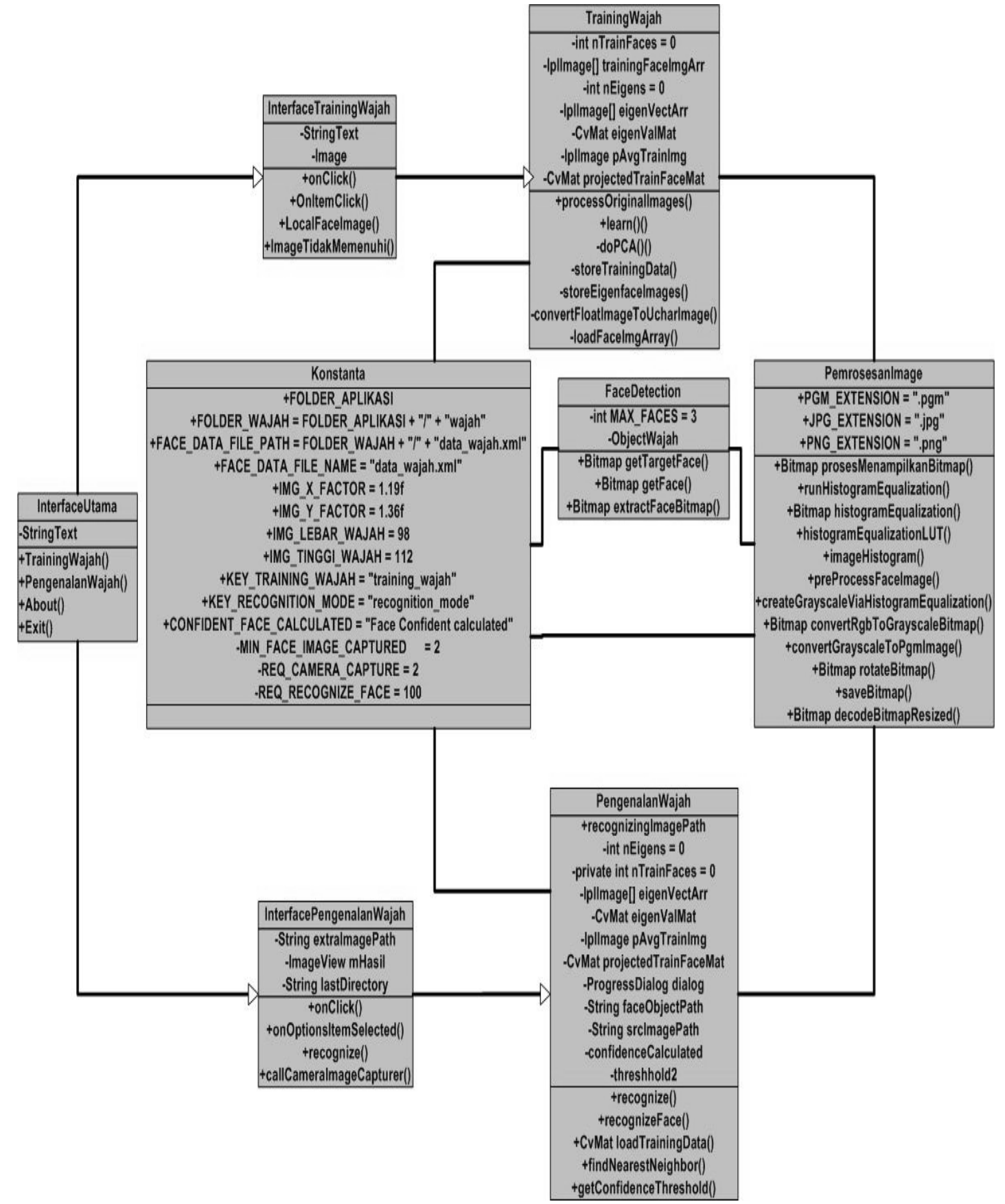

Gambar 6. Class Diagram aplikasi identifikasi wajah 
Citec Journal, Vol. 1, No. 1, November 2013 - Januari 2014

\section{HASIL DAN PEMBAHASAN}

berikut:

Rancangan sistem diaplikasikan dengan spesifikasi hardware dan software sebagai

1. Prosesor Intel core 2 duo E7500 @ 2.93Ghz

2. RAM 1GB

3. Harddisk $320 \mathrm{~GB}$

4. VGA Card Nvidia GeForce 9500GT

5. Monitor

6. Sistem Operasi Windows XP

7. Eclipse versi 3.7.0 sebagai tools pengembangan aplikasi

8. Android SDK versi 20.0.3 sebagai library dari android

9. JDK untuk compiler versi 1.6.

10. Library JavaCV

11. CorelDRAW X4 untuk pembuatan icon

Aplikasi face recognition yang dihasilkan diinstal pada smartphone Android versi 2.3.4 sehingga pada layar smartphone akan muncul icon aplikasi seperti pada gambar 7.

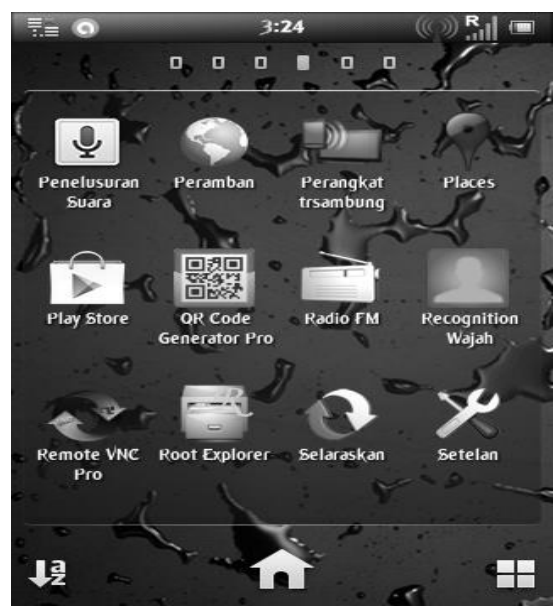

Gambar 7. Icon Aplikasi face recognition

Saat aplikasi dijalankan pertama kali akan muncul menu utama terdiri dari buttontraining, button pengenalan, button about dan button exit seperti pada gambar 8 .

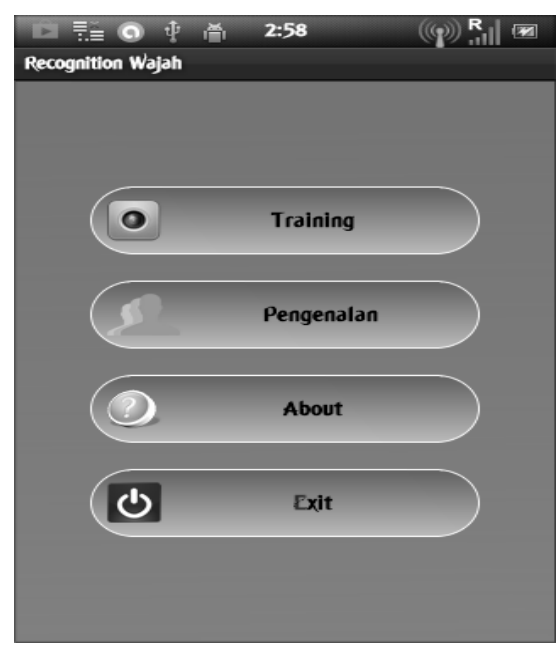

Gambar 8. Menu Utama 
Training wajah digunakan untuk menyimpan wajah pemilik smartphone yang terdiri dari button kamera yang digunakan untuk menampilkan fungsi kamera handphone, button proses digunakan untuk memproses image, imageview digunakan untuk menampilkan hasil image yang telah diambil, dan gallery yang berfungsi menampilkan beberapa gambar yang telah diambil seperti pada gambar 9.

Pemilik smartphone menggambil 6 posisi wajah yang berbeda. Hal ini supaya proses unlock phone posisi wajah menjadi lebih mudah, tidak terpaku pada posisi tertentu saja akan tetapi dapat melalui beberapa posisi seperti pada gambar 10.

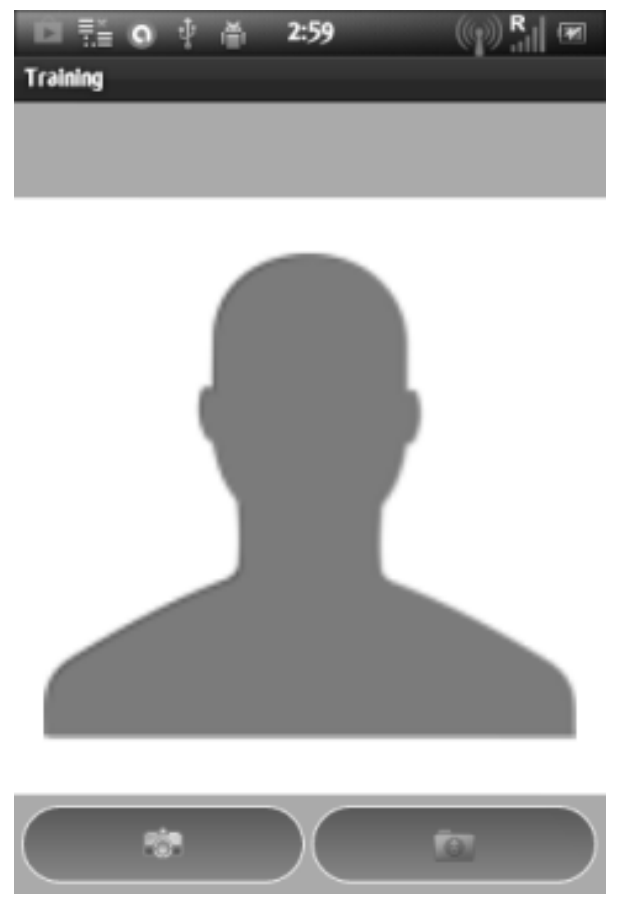

Gambar 9. Tampilan training wajah
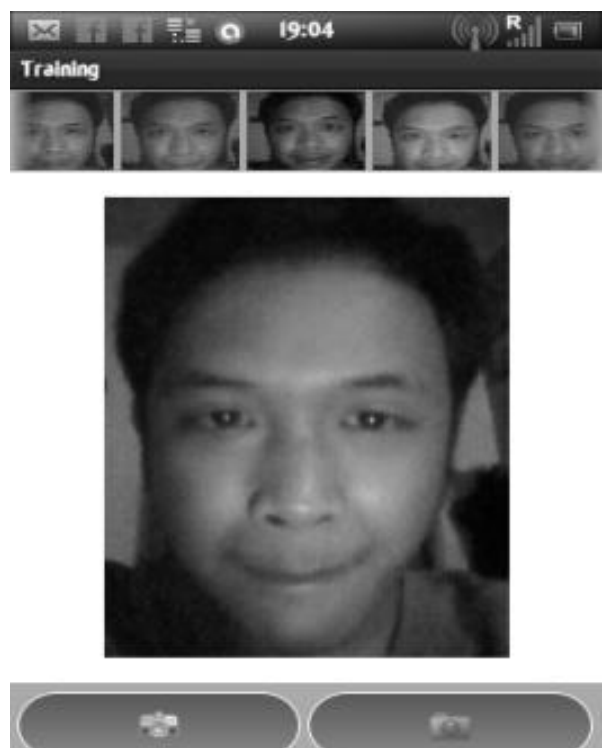

Gambar 10. Proses training wajah 
Citec Journal, Vol. 1, No. 1, November 2013 - Januari 2014

ISSN: 2354-5771

Pengenalan Wajah adalah tampilan yang akan muncul pada saat button pengenalan dipilih, atau pada saat smartphone dalam keadaan terkunci (lock). Menu pengenalan wajah terdapat beberapa komponen antara lain adalah button kamera yang digunakan untuk menampilkan fungsi kamera, button recognition yang berfungsi untuk memproses pengenalan wajah seperti pada gambar 11 dan gambar 12.

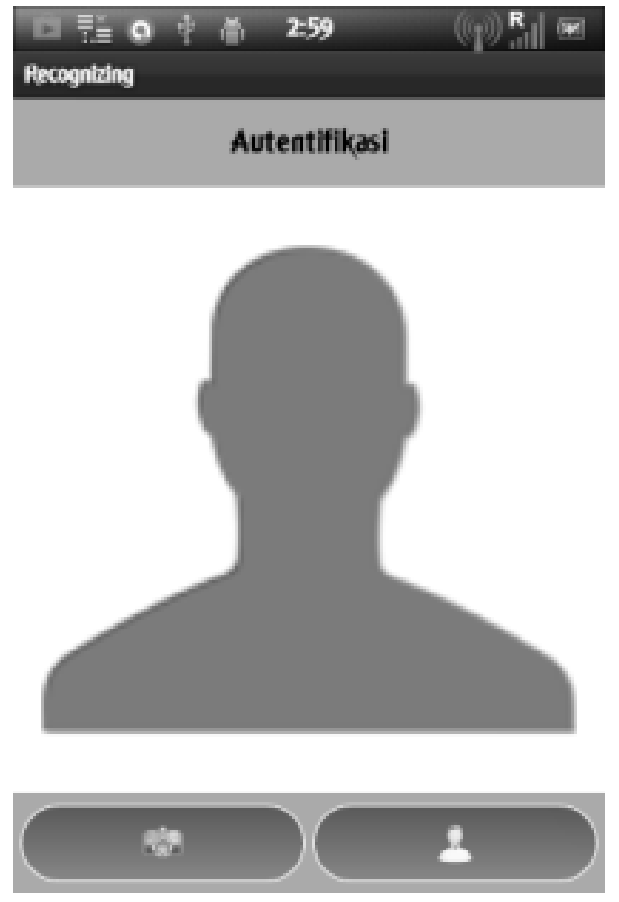

Gambar 11. Tampilan pengenalan wajah
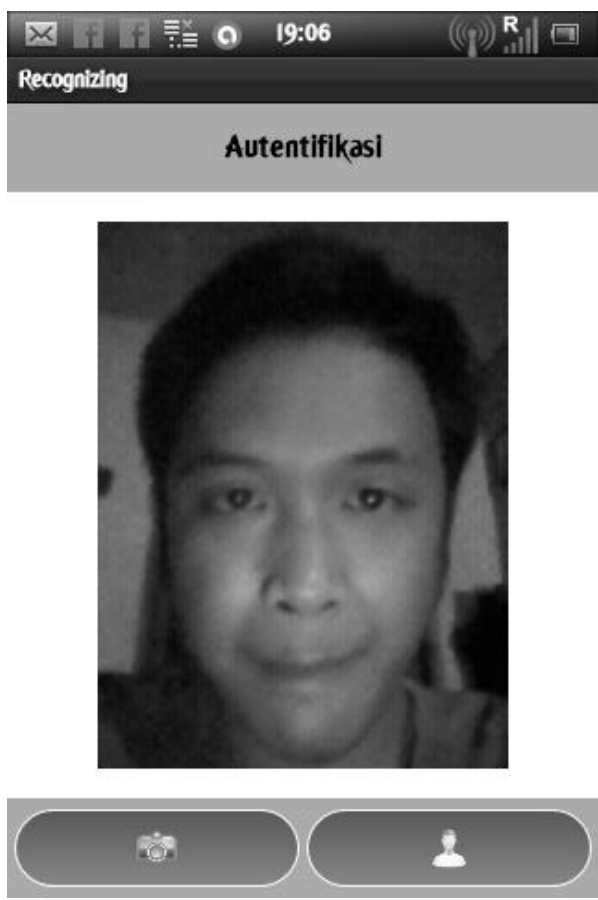

Gambar 12. Proses pengenalan wajah 
Penerapan pointwise pada penelitian ini digunakan untuk merubah image berwarna (true color) menjadi gray scale. Proses ini terjadi pada saat proses training dan identifikasi wajah pengguna melalui proses yang sama. Perbedaan proses training wajah dengan identifikasi wajah adalah proses training wajah pada penyimpanan image (data_wajah.xml), sedangkan proses identifikasi wajah adalah proses pencocokan data (face recognition). Proses training wajah dan face recognition untuklebih jelas dapat digambarkan dengan flowchart pada gambar 13 dan gambar 14.

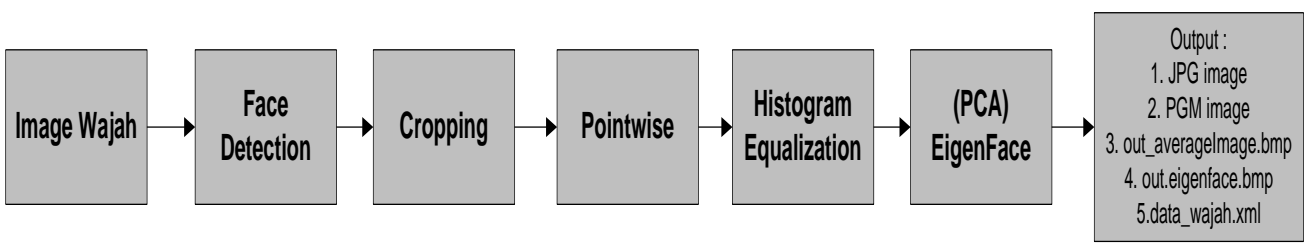

Gambar 13. Proses Training Wajah

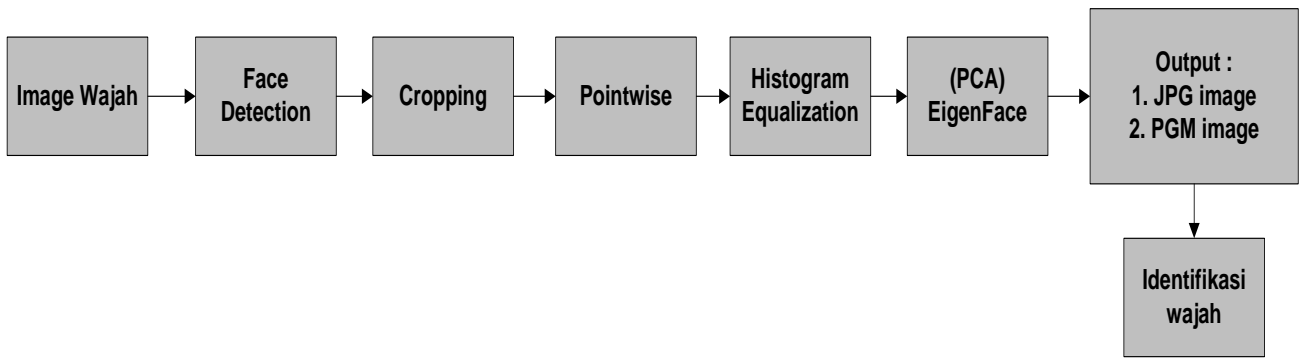

Gambar 14. Proses Identifikasi Wajah

Pengujian aplikasi face recognition dilakukan dengan cara pengguna melakukan training wajah dengan 6 pose berbeda dengan cahaya normal dan jarak kamera dengan wajah konstan. Posisi wajah saat training dilakukan dengan beberapa kriteria yaitu:

1. Wajah menghadap lurus ke arah kamera.

2. Wajah dengan pose yang unik atau lucu menghadap lurus ke arah kamera.

3. Wajah 5 derajat kearah samping kanan dari depan kamera.

4. Wajah 5 derajat kearah samping kiri dari depan kamera.

5. Wajah 5 derajat kearah atas dari depan kamera.

6. Wajah 5 derajat kearah bawah dari arah kamera.

Identifikasi wajah dilakukan dengan pengambilan 40 image wajah, dimana 20 adalah wajah pengguna yang memiliki hak masuk dan 20 adalah pengguna yang tidak memiliki hak masuk. Pengujian juga dilakukan dengan tingkat pencahayaan dan jarak yang berbeda agar bisa diambil kesimpulan, hasilnya tercantum pada tabel 3, tabel 4, tabel 5 dan tabel 6 .

Tabel 3. Pengujian dengan tingkat cahaya normal dan jarak berbeda

\begin{tabular}{|l|c|c|c|c|}
\hline \multicolumn{1}{|c|}{ Pengujian Dengan Tingkat Cahaya Normal dan Jarak Berbeda } \\
\hline Wajah Tes & $\begin{array}{c}\text { Banyaknya } \\
\text { Input } \\
\text { Wajah Tes }\end{array}$ & Dikenali & $\begin{array}{c}\text { Tidak } \\
\text { Dikenali }\end{array}$ & $\begin{array}{c}\text { Gagal Saat } \\
\text { Identifikasi }\end{array}$ \\
\hline $\begin{array}{l}\text { Wajah pengguna yang memiliki hak } \\
\text { masuk }\end{array}$ & 20 & 15 & 3 & 2 \\
\hline $\begin{array}{l}\text { Wajah Pengguna yang tidak memiliki } \\
\text { hak masuk }\end{array}$ & 20 & 3 & 14 & 3 \\
\hline
\end{tabular}


Citec Journal, Vol. 1, No. 1, November 2013 - Januari 2014

ISSN: 2354-5771

Hasil pengujian pada tabel 3 menunjukkan bahwa:

1. Persentase kecocokan antara wajah training dengan wajah yang memiliki hak masuk adalah sebesar $\frac{15}{20} \times 100 \%=75 \%$.

2. Persentase Keberhasilan ketidakcocokan antara wajah training dengan wajah yang tidak memiliki hak masuk adalah sebesar $\frac{14}{20} \times 100 \%=70 \%$.

Tabel 4. Pengujian dengan Cahaya Normal dan Jarak Konstan

\begin{tabular}{|l|c|c|c|c|}
\hline \multicolumn{5}{|c|}{ Pengujian Dengan Tingkat Cahaya Normal dan Jarak Konstan } \\
\hline Wajah Tes & $\begin{array}{c}\text { Banyaknya } \\
\text { Input } \\
\text { Wajah Tes }\end{array}$ & Dikenali & $\begin{array}{c}\text { Tidak } \\
\text { Dikenali }\end{array}$ & $\begin{array}{c}\text { Gagal Saat } \\
\text { Identifikasi }\end{array}$ \\
\hline $\begin{array}{l}\text { Wajah pengguna yang memiliki hak } \\
\text { masuk }\end{array}$ & 20 & 18 & 1 & 1 \\
\hline $\begin{array}{l}\text { Wajah Pengguna yang tidak memiliki } \\
\text { hak masuk }\end{array}$ & 20 & 1 & 17 & 2 \\
\hline
\end{tabular}

Hasil pengujian pada tabel 4 menunjukkan bahwa:

1. Persentase kecocokan antara wajah training dengan wajah yang memiliki hak masuk adalah sebesar $\frac{18}{20} \times 100 \%=90 \%$.

2. Persentase Keberhasilan ketidakcocokan antara wajah training dengan wajah yang tidak memiliki hak masuk adalah sebesar $\frac{17}{20} \times 100 \%=85 \%$.

Tabel 5. Pengujian dengan Tingkat Cahaya Terang dan Jarak Konstan

\begin{tabular}{|l|c|c|c|c|}
\hline \multicolumn{6}{|c|}{ Pengujian Dengan Tingkat Cahaya Terang dan Jarak Konstan } \\
\hline Wajah Tes & $\begin{array}{c}\text { Banyaknya } \\
\text { Input } \\
\text { Wajah Tes }\end{array}$ & Dikenali & $\begin{array}{c}\text { Tidak } \\
\text { Dikenali }\end{array}$ & $\begin{array}{c}\text { Gagal Saat } \\
\text { Identifikasi }\end{array}$ \\
\hline Wajah pengguna yang memiliki hak masuk & 20 & 14 & 4 & 2 \\
\hline Wajah Pengguna yang tidak memiliki hak masuk & 20 & 1 & 17 & 2 \\
\hline
\end{tabular}

Hasil pengujian pada tabel 5 menunjukkan bahwa:

1. Persentase kecocokan antara wajah training dengan wajah yang memiliki hak masuk adalah sebesar $\frac{14}{20} \times 100 \%=70 \%$.

2. Persentase Keberhasilan ketidakcocokan antara wajah training dengan wajah yang tidak memiliki hak masuk adalah sebesar $\frac{17}{20} \times 100 \%=85 \%$. 
Tabel 6. Pengujian dengan Tingkat Cahaya Rendah dan Jarak Konstan

\begin{tabular}{|l|l|l|l|l|}
\hline \multicolumn{6}{|c|}{ Pengujian Dengan Tingkat Cahaya Rendah dan Jarak Konstan } \\
\hline \multicolumn{1}{|c|}{ Wajah Tes } & $\begin{array}{c}\text { Banyaknya } \\
\text { Input } \\
\text { Wajah Tes }\end{array}$ & Dikenali & $\begin{array}{c}\text { Tidak } \\
\text { Dikenali }\end{array}$ & $\begin{array}{c}\text { Gagal Saat } \\
\text { Identifikasi }\end{array}$ \\
\hline Wajah pengguna yang memiliki hak masuk & 20 & 14 & 4 & 2 \\
\hline $\begin{array}{l}\text { Wajah Pengguna yang tidak memiliki hak } \\
\text { masuk }\end{array}$ & 20 & 1 & 17 & 2 \\
\hline
\end{tabular}

Hasil pengujian pada tabel 6 menunjukkan bahwa:

1. Persentase kecocokan antara wajah training dengan wajah yang memiliki hak masuk adalah sebesar $\frac{14}{20} \times 100 \%=70 \%$.

2. Persentase Keberhasilan ketidakcocokan antara wajah training dengan wajah yang tidak memiliki hak masuk adalah sebesar $\frac{17}{20} \times 100 \%=85 \%$.

\section{KESIMPULAN}

Berdasarkan Implementasi dan penjelasan yang telah dipaparkan sebelumnya, maka dapat diambil kesimpulan dari aplikasi identifikasi wajah menggunakan metode eigenface berbasis android sebagai berikut:

1. Aplikasi ini dapat mengidentifikasi wajah menggunakan metode eigenface berbasis android yang diterapkan pada face unlock sebagai autentifikasi user untuk menggantikan PIN dan password dengan tingkat keberhasilan antara 70\% sampai $90 \%$.

2. Jarak antara wajah dan kamera serta tingkat kecerahan cahaya mempengaruhi hasil dari identifikasi wajah. Tingkat keberhasilannya ditentukan oleh pengambilan image, pemrosesan image, dan perhitungan dengan PCA (eigenface).

\section{SARAN}

Aplikasi face recognition akan lebih optimal jika digunakan pada smartphone yang menggunakan kamera statis dan kondisi ruangan dengan tingkat pencahayaan maupun jarak stabil.

\section{DAFTAR PUSTAKA}

[1] Ahmad, U., 2005, Pengolahan Citra Digital dan Teknik Pemrogramannya, Edisi 1, Graha Ilmu, Yogyakarta.

[2] Ridwan, F., Mengenali Lebih Jauh Apa Itu Point Process,

http://ilmukomputer.org/2011/03/14/mengenal-lebih-jauh-apa-itu-point-process, diakses tanggal 5 Desember 2012.

[3] Fatta, H. A., 2009, Pengenalan Wajah dengan Menggunakan Algoritma Eigenface, Jurnal Penelitian.

[4] Siregar, I. M., Yusuf, R., Siendow, W., Wino, W. W., 2010, Mengembangkan Aplikasi Enterprise Berbasis Android, Gava Media, Yogyakarta.

[5] Rifqi, Instalasi JavaCV, http://rifqithokz.wordpress.com, diakses 2 Januari 2013. 